日臨外会誌 $63(4), 14.31-111,3,2014$

症 例

膀胱癌に合併した自己免疫性膵炎の 1 例

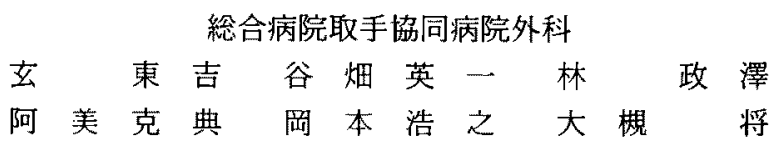

症例はで歳, 男性, 膀胱癌にて膀胱全摘術後鼠径部リンパ節転移に対し放射線療法施 行. 5 力月㣪閉塞性黄疸出現し PTCD 捕入。腹部エコー, CT, PTCD 造影検查で下部 胆管の閉塞と膵頭部の腫大を認める以外異常はなかった。 ERCP 検查ては膵内胆管の平 滑な全周性狭窄を認め, NIRI 検查で主膵管は膵頭部で狭細化し，膀体尾部では拡張を認 めなかっだ、膵頭部癌も否定でず手術を施行した。膵はびまん性に硬く膵組織の術中 迅速病理検查では慢性膵炎と診断さ机胆管空腸吻合術を施行した．切除胆管と膵の組織 像では，著明な線維化とリンパ球や形質細胞の炎症細胞浸潤を認めた，血液検查で好酸 球增多症, 高 $\gamma$ グロブリン血症, IgG 高值, 自己免疫抗体陽性を示し, 自己免疫性膵炎 と考えられた． て力月後リンパ節転移は再燃し，膀胱癌の骨転移により死亡した．自己 免疫性脺炎は下部胆管狭窄に上る閉塞性黄疸の鑑別㟝断として重要であり，悪性腫傷と の合併も考虑すべきであると考えられた。

索引用語：脺頭部，自己免疫性膵炎，膀胱癌

はし゚めに

近年, 自己免疫異常の関与が強く示唆され，副腎皮 䁈ステロイド投与が有効で, 臨床的, 形態学的に特徽 示す自己免疫性膵炎"という概念が注目され数多く 報告されてきている。

自己免疫性疾患と悪性腫堭の合併についてはこれま ても多くの報告があるか，自己免度性膵炎においては いまだ悪性腫湟合併例は報告されていない，今回われ われは, 膀睄癌鼠径部リンパ節転移に刘し放射線療法 後自己免疫性萃炎を合併し，骨など全身に転移した症 例を経験したので,若干の文献的考察を加え報告する。

$$
\text { 泟例 }
$$

患者：行歲，男性.

主訴：黄疸.

家族歴：特記事項なし。

既往歴：43歳, 糟㽷病. 68 瓷, 膀胱癌で膀胱全摘術. 飲酒歷，契煙歴なし。

現病歴：1998年6月2日膀胼癌で膀胱全摘, 新膀胱

2003年12月19日受付 200 (304年1月21日採用 所属施設住所〉

于3020022 取手市本榔 2-1-1
造成衔 $(\mathrm{G} 3>\mathrm{G} 2, \mathrm{pT} 3 \mathrm{~b}, \mathrm{pN} 2)$ 施行. 2000 年 8 月 鼠径部リンパ節転移に対し放射線療法 (60Gy 照射) 施 行. 2001 年 1 月中旬頃褐色尿出現. 同年1月21日総ビ リルビンは $18 \mathrm{mg} / \mathrm{dl}$ と上昇, 腹部エコー, CT 検查で閉 塞性黄疸と䛦断され緊急入院となり PTCD施行. PTCD 造影検查では総胆管は，三管合流部以下で完全 に途絶され脺頭部癌が疑われたが家族の希望により外 㭅で経過観察していた。減黄後症状なく経過したため, 精查目的で同年 3 月 31 日外科入紹介入院となった.

入院時現症：身長 $164 \mathrm{~cm}$, 体重 $56 \mathrm{~kg}$ ，栄湌良。眼瞼 結膜に瑻血はなく眼球結膜に軽度の黄染を認めた。腹 部は平坦, 軟で圧痛はなく, 左肋弓下に PTCD 垀入硘 と下腹部正中に手誧瘵痕創を認めるも腫瘤は触知しな かつた.

入院時検査成績：血算, 生化学唡查では軽度の総ビ リルビン值上昇と高血精を認める以外は正常範囲であ った。腫瘍マーカーでは CEA 8.0mg/dl, CA19-9 202 IU/1 と上昇を認めだ. 胆汁細胞診はclass 3 a であっ た。

ヘリカル CT 所見：膵体尾部の腫大はなく（図 1

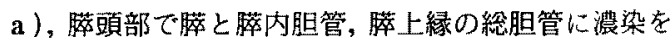
認め(図 1 b， d)，脺頭部は軽度に腫大していた（図 


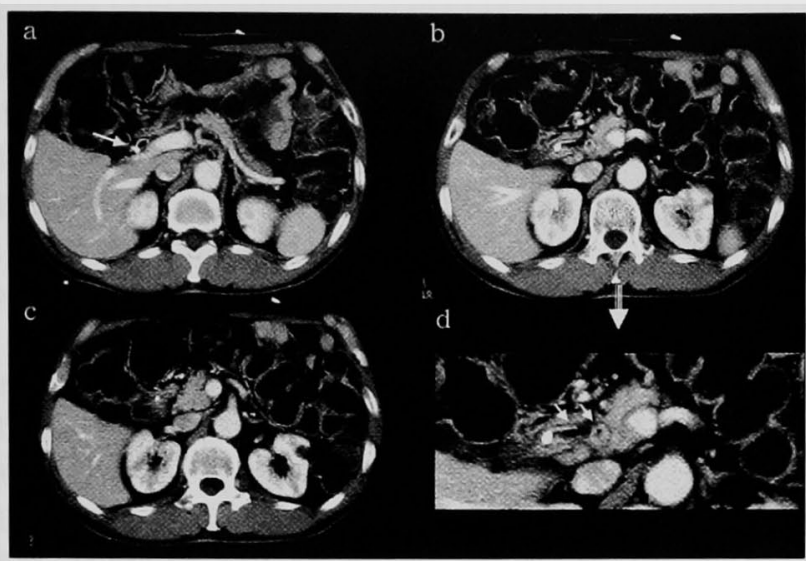

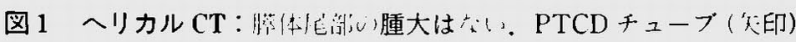

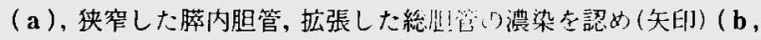
d), 膵頭部は軽度に腫大していた（c）。

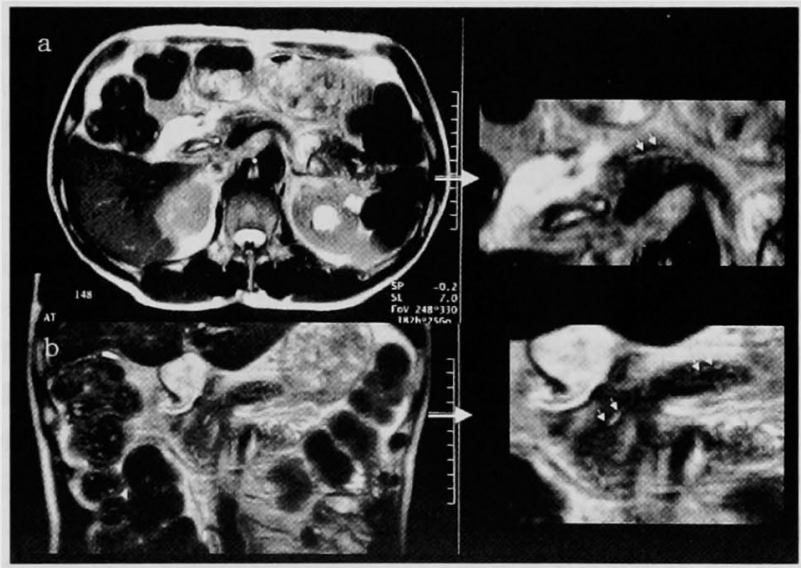

図 2 腹部 IRI：膵体部の膵管に拡张はない(矢印)（a）.脺頭部の 膵管はやや狭細化し描出不良であるか，尾部の膵管に拡張や途絶は ない（矢印）（b）。

1 c ）、明らかな腫瘤性病変は認められなかった。

腹部 MRI 所見：槅体湖ひ)膵管に拡張はなく（図2 a ), 膵頭部の膵管はやや狭細化し描出不良であるか， 尾部膵管の拡張や途絶は認められ去かった（図 2 b).

ERCP 所見：膵内下部胆管に全周性の平滑な狭窄 を認めた。内腔は $1 \mathrm{~mm}$ 以下で高度に狭窄していたか， 主膵管は描出されなかった（図３）。

腹腔動脈造影扩よび angio CT 検查施行するも脺頭 部の腫大以外胆管閉塞部位に明らかな腫瘤性病変は同 定できなかった.脺内胆管の全周性の滑らかな狭窄は，
慢性膵炎の線維化による締め付けのようにもみえた か，悪性腫場も否定できず2001年 + 月23日開腹術を施 行した.

術中所見：膵:作は白色調を呈し弾性硬で，特に膵 頭部では硬く腫大していた．膵頭部を授動し十二指腸 乳頭部から膵内胆管，膵頭部を検索するも腫瘤性病変 は触知しなかった，膵周囲のリンパ節も硬く腫大して おり，膵頭部癌も完全には否定出来なかった，膵頭部 の膵組織とリンパ節の術山迅速病理検査でけ，悪性像 はなく慢性炎症の像を呈していた。慢性膵炎による膵 


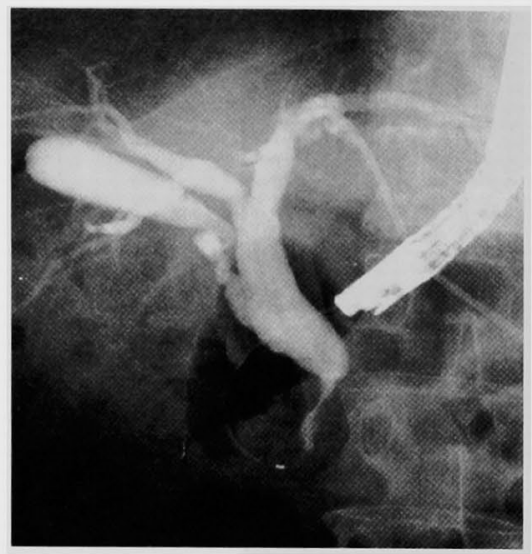

図 3 ERCP：脺内胆管の全周性, 平滑な高 度の狭窄を認める。

頭部腫大と診断し, 膵上縁で総胆管を切離, 胆亯と伴 に総肝管を切断㷋，胆管空腸吻合術を施行した。

病理組織学的所見：膵組織はほとんど線維化され著 明なリン八球, 形質細胞の浸潤を認め慢性膵炎と診断 されたた(図 $4 \mathbf{a}, \mathbf{b}$ ). 胆夜管合流部で切除された総胆 管壁は肥厚し著しい線維化と炎症細胞の浸潤が認めら 机た（図４c，d）。

臨床経過と画像, 病理組織検査の結果, 自己免疫性 膵炎が疑われたため, 術後免疫生化学的検查を行った。

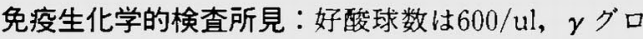
ブリン值は25。で好酸球増多症, 高 $\gamma$ グロブリン血症 を認め, IgG $24 \mathrm{~g} / \mathrm{l}, \mathrm{RF} 773 \mathrm{IU} / \mathrm{ml}$ と高值であった。抗 DNA 抗体 (ss-DNA) 40倍, 抗核抗体 (homogenous pattern, speckled pattern) 40倍, 免疫複合体 IC (Clq) $\tau .4 \mu \mathrm{g} / \mathrm{ml}$ と上昇し, 血清補体価 C $30.47 \mathrm{~g} / \mathrm{l}, \mathrm{C} 4$ $0.06 \mathrm{~g} / 1$ と低值を示し自己抗体は陽性で自己免疫性膵 炎上考えられた。

糖尿病と新膀胱㿉のため易感染状態と判断し術後ス テロイド投与は行わなかったか，順調に経過し2001年 5 月23日退院した。2001年11月鼠径部リンパ節転移再 然，2002年 8 月腰背部痛出現し骨シンチ検査で骨転移 がみられ，泌尿器科で精查の結果膀胱癌の転移と診断. 化学療法および放射線療法を試みるも全身に癌は広が り2003年 1 月13日亡くなった。家族の意志により剖検 は施行できなかった。

\section{考 察}

自己免疫性膵炎は通常びまん性の膵腫大や膵管狭細 像を示す症例が中心であり, 高 $\gamma$ グロブリン血症, 高
IgG 血症や自己抗体の存在，ステロイド治療が有効な ど，自己免疫機序の関与を示唆する所見を伴うとしと ている. 本症例も術後免疫生化学検査で高 $\gamma$ グロブリ ン血症や自己抗体を認め, 組織学的検査でも膵組織の 線維化と著明なりンパ球, 形質細胞の浸潤がみられた。 膵管狭細像を伴う膵腫大はびまん性でなく膵頭部に限 局していたが自己免疫性膵炎の概念に一致すると思わ れた。

康ら は) は自験を含め腫瘤形成や限局性腫大をきたし た脺管狭細型慢性膵炎18例を集計し限局性病変の存在 を示唆している．膵体部に腫瘤を形成し限局性に膵管 狭細像を示し，膵管狭細型膵炎にみられるような組織

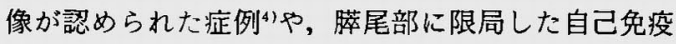
性膵炎の報告例 ${ }^{5}$ もる。限局性膵腫大が起こるのは, 炎症や線維化の程度により，病悩期間の一時期を捉え ているのではないかと推測される。

自己免疫性膵炎のなかには他の自己免疫性疾患の合 併を認める症例も数多く報告されており，特にシェ一 グレン症候群や原発性硬化性胆管炎（以下, PSC) の 合併例は多い。渡辺 ${ }^{6}$ は本邦で自己免疫性膵炎と思わ れる17症例を集計し，5例にシェーグレン症候群， 3 例に PSC を認め, 岡崎ら”は自験20例中 3 例にシェー グレン症候群，3例に PSC，45\%に他の自己免疫性疾 患の合併を認めたと述べている.PSCの全国調查で 192例中29例 $(15.0 \%)$ に慢性膵炎の合併を認めてお $\eta^{81}$ ，この中には自己免疫性膵炎も含まれていると思 わ北る、自己免疫性膵炎と PSC との異同が問題となっ ているが，一般的にはステロイドに対する反応予後が 異なり別の病態ではないかとされている.

自己免疫性膵炎の胆管病変の合併は, 厚生省研究全

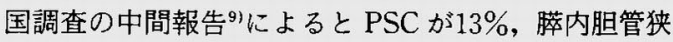
窄か８２\% とされている。自己免疫性萃炎の病理組織学 的特徴であるリンパ球と形質細胞の浸潤と線維化は, 程度の差はあるがほほ全域の胆管壁に認められ，胆亯 も胆管壁ほどではないが同様の炎症を認める(0). 本症 例は術前 ERCP 検査で拡張していた膵内切除断端上 部の総胆管壁に著明なリンパ球と形質細胞の浸潤と線 維化を認めたが，胆管狭窄は膵内だけにみられた．全 周性で平滑な下部胆管狭窄は脺内に限局し, 膵実質の 炎症，線維化による圧迫が原因と考えられた。

自己免疫性膵炎におけるCT の特徵は膵で後期に造 影されてくる delayed enhancement が特徴とされて いる ${ }^{111}$. 本症例でも腫大した脺頭部だけでなく膵体尾 部および脺内胆管にも delayed enhancement が認め 


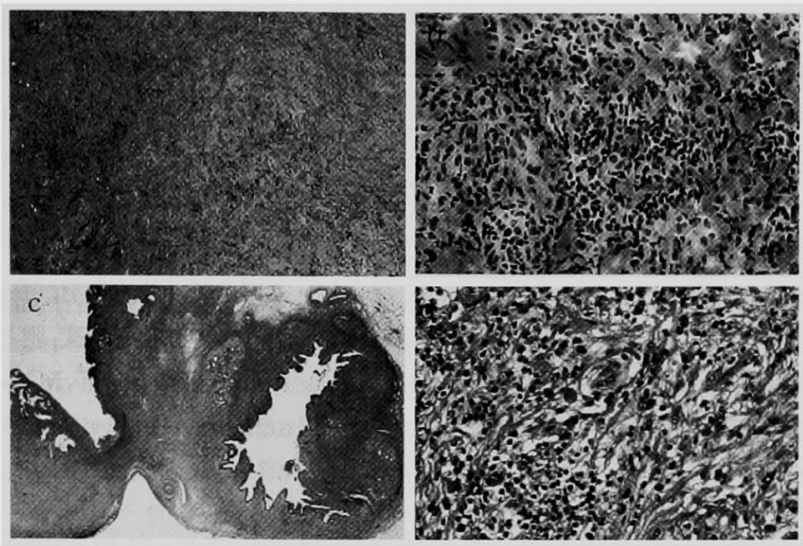

図４病理組織所見：脺組織はほとんど線維化され（H.E. $\times 10(a)$.

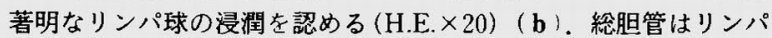
球浸潤に伴う線維性の壁肥厚を認める(H.E. × 4) (c). 総胆管壁 内に炎症細胞の浸潤を認める (H.E. 20) (d).

られた。これは病変部の線維化を反映していると考え られた．本症例ではへリカル CT 検査において狭窄し た膵内胆管だでなく拡張している総胆管壁にも全周 性の肥厚と造影増強所見を認め，炎症細胞浸潤と線維 化を反映していると推測された，胆管壁肥厚は脺内胆 管壁への炎症波及や胆管自体の炎症も考えられる．胆 管壁の炎症は，PTCD チューブ留置による影響を考慮 しても，脺実質の組織像に類似していた点から，胆管 に対する自己免疫的機序による炎症ではないかと考え られる．本庶ら ${ }^{121}$ は自己免疫性脺疾患に合併する胆管 病変は, PSC とは異なり膵病変と共通の機序による自 己免疫関連膵・胆管炎と考えられると報告している. 胆管壁の炎症の程度は, 細胞浸潤が主体か, 線維化が 主体かによりステロイド投与の効果に差があるのでは ないかと述べている．本症例は造影 CT 検査で胆管壁 の造影增強があり炎症細胞浸潤が主体と考えられ，ス テロイド投与が有効であったかもしれない.

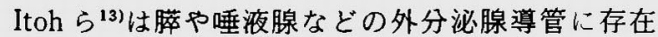
する炭酸脱水素酵素 II (carbonic anhydrase II, CA II）の自己抗体である抗 CA II抗体がシェーグレン症 候群で検出されることを報告した，自己免疫性脺炎で も抗 CA II抗体が検出されステロイド投与により抗体 価は隇少し, 膵腫大と臨床症状も改善したとの報告 ${ }^{14)}$ 以来，シェーグレン症候群の合併例は多く報告されて いる ${ }^{15)}$. シェーグレン症候群は膠原病に乾燥性角結膜 炎, 口腔乾燥症を合併し, 外分泌腺の自己免疫疾患で あり, 自己免疫性膵炎の脺病変は涙腺や唾液腺病変と
同様，膵管に対する自己免疫応答が直接の原因と考え られている。

皮莒筋炎や多発性筋炎などの膠原病に悪性腫瘍の合 併は広く知られている。シェーグレン症候群と悪性り ンパ腫の密接な関連は広く認識されている 器腫瘍だけでなく固形腫瘍も報告されてきている 本邦文献上検索した限りでは，自己免疫性膵炎に悪性 腫瘍の合併例は報告されていないか，自己免疫性膵炎 とシェーグレン症候群との密接な関係から覀性腫瘍と の関連も今後の課題になると思われる.

自己免疫性膵炎の病理組織学的特徵は脺の著明なり ンパ球や形質細胞の炎症性細胞浸潤と膠原線維の増生 が特徵て、このリンパ球は免疫組織学的に CD 4 陽性 T cell リンパ球が主体であることが多く CD 8 陽性り ンパ球も認められる ${ }^{18)}$.このCD4と CD 8 の T 細胞 サブセットの不均衡 ${ }^{199}$ から T 細胞機能異常が起き, 自 己免疫性膵炎でも免疫系などのバランスが崩れている と推測される. 本症例は $\mathrm{CD} 4, \mathrm{CD}$ \&の採血は行って いないが， T cell と B cell の細胞比は正常範囲であっ た. Cummings ら ${ }^{20)}$ は，自己免疫性疾患に悪性腫瘍の 合併が多い原因として，免疫系の遺伝的異常素因を基 盤に免疫異常を生じた場合，抗体産生系 B 細胞の機能 六進が起こり，自己免疫疾患が発症する，一方で細胞 免疫性 $\mathrm{T}$ 細胞の機能低下加ら免疫監視機構の破綻を 招くと悪性腫演の発生の方向にも進む．すなわち，遺 伝的免疫異常という同じ基盤に基づいて，自己免疫性 疾患，悪性腫疸が表現型の違いとして発現するとして 
いる。

本症例は, 膀胼癌術後鼠径部リンパ節転移に対する 放射線療法後，比䡈的短期間で自己免疫性脺炎が発症 した，その数力月位，鼠径部リンパ節転移は再燃し， 骨など全身に転移が広がったことから，前述の遺伝的 素团の他，放射線療法や化学潦法も免疫系統の不均衡 を促進させた要因ではないかと考えられた。

結語

今回, 膀胱癌術後膵頭部の腫大を認め, 閉塞性黄疸 を合併した自己免疫性膵炎の症例を経験したので若干 の文献的考察を加えて報告した。

\section{文献}

1) Yosida K, Toki F, Takeuchi T, et al : Chronic pancreatitis caused by an autoimmune abnormality. Proposal of the concept of autoim. mune pancreatitis. Dig Dis Sci $40: 1561-1568$, 1995

2）岡崎和一, 浅田全範, 内田一茂他：自己免疫異常 と膵炎。最新医 $57: 2557-2562 ， 2012$

3）康純明, 久保尚士, 新田敦範他: 腪溜形成扝上 びリンパ節腫大を伴った膵管狭細型慢性膵炎の 1 例。胆と脺 20：1043-1047，1999

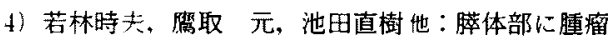
形成した，いわ功る限局性膵管狭細型慢性脺炎 の 1例。脺臓 16:25-32，2001

5) Koga $\mathrm{V}$. Yamaguchi $\mathrm{K}$, Sugitani $A$, et al: Autoimmune pancreatitis starting as a localized form. J Gastroenterol 37:133-137, 2002

6）渡辺伸一郎：自己免疫性脺尖胆と脺 $17: 239-$ 244,1996

7) 阙崎和一, 浅田全範, 内田一茂他：自己免疫性膵 炎。胆と猝 $23: 685-691,2002$

8）滝川一, 高森頼雪：かが国における原発性硬化 性胆管炎の疫学。肝・胆・膵 $32: 13-17,1996$

9）西森 功, 須田耕一, 大井 至他: 自己免疫性膵 炎。日消病会誌 $97 ： 1355-1363 ， 2000$
10）神澤矮実，船田信顕，鶴田耕二地：自己免疫性膦 炎と関連病変の病理. 消画像 $4: 25-29,2002$

11) Furukawa $N$, Muranaka $T$. Yasumori $K$, et al: Autoinmune pancreatitis: Radiologic findings in three histologically proven cases. J Comput Assist Tomogr 22:880-883, 1998

12）本庶 元，竹内和男，長島夏子地：自己免渡性脺 炎に抢ける胆管病変.胆と膵 $22 ： 581-587,2001$

13) Itoh $Y$, Reichlin $M:$ Antibodies to carbonic anhydrase in systemic lupus erythmatosus and other rheumatic disease. Arthritis Rheum 35: 73-82, 1992

14) Ito $T$, Nakano I, Koyanagi $S$, et al: Autoimmune pancreatitis as a new clinical entity. Three cases of autoimmune pancreatitis with effective steroid therapy. Dig Dis Sci $12: 1458$ $-1468.1997$

15）西森 功，森本香里，大西三郎：自己免疫性脺炎 とシェーダレン症候群。消画像 4：79-83,2002

16) Talal N, Bunim JJ : The development of malignant lymphoma in the course of Sjögren's syndrome. Am J Med 36:529-540, 1954

17) 河野 厚, 郡山建治, 有森 茂：乳癌と B Cell Type 悪性リンバ腫を合併したSjogren 症候群。 リウマチ $30: 388-395,1990$

18) Utida K, Okazaki K, Konoshj $Y$, et al :Clinical analysis of autoimmune-related pancreatitis. Am J Gastorenterol 95 : 2788-2794, 2000

19) Morimoto $C$, Reinherz EL, Nadler LM, et al: Comparison $\mathrm{T}$ and $\mathrm{B}$ cell markers in patients with Sjögren's syndrome and SLE. Clin Immunol Immunopathol $22: 270-275,1982$

20) Cummings NA. Shall GL, Asofsky R, et al: Sjögren's syndrome newer aspects of research, diagnosis and therapy. Ann Int Med 75 : 937950, 1971 


\title{
A CASE OF AUTOIMMUNE PANCREATITIS WITH BLADDER CANCER
}

\author{
Tokichi GEN, Eiichi YABATA, Seitaku HAYASHI, \\ Katsunori AMI, Hiroyuki OKAMOTO and Sho OTSUKI \\ Department of Surgery, Toride Kyodo General Hospital
}

A 70-year-old man, treated with radiotherapy to inguinal lymph node metastasis after cystectomy for bladder cancer, underwent percutaneous transhepatic cholangiodrainage (PTCD) becaused obstructive jaundice developed five months after the radiotherapy. Abdominal ultrasonography and computed tomography. PTCD tube-cholangiography showed no abnormalities except stenosis of the lower common bile duct and swelling of the pancreatic head. Endoscopic retrograde cholangiopancreatography revealed smooth stenosis encirculing the lower common bile duct in the head, magnetic resonance imaging scan showed tapering narrowing of the main pancreatic duct in the head without showing no dilatation of the pancreatic body and tail. He underwent laparotomy because cancer of the pancreatic head could not to be ruled out completely. Cholangiojejunostomy was performed because intraoperative rapid biopsy of the diffuse hard pancreas gave the histopathological diagnosis of chronic pancreatitis. The excised pancreas and bile duct revealed severe fibrosis at the pancreatic parenchyma and infiltration of inflammatory cells including lymphocytes and plasma cells. Postoperative immunochemical study suggested autoimmune pancreatitis ; eosinophilia, hyper $\gamma$-globulinemia, elevated $\lg G$ and positive responses to autoantibodies. The inguinal lymph node matastasis recurred seven months after the operation and the patient died of bone metastasis of bladder cancer. It is considered that autoimmune pancreatitis is very important as differential diagnosis of obstructive jaundice with stenosis of the lower common bile duct. 